\title{
Adaptation to climate change in coastal communities: findings from seven sites on four continents
}

\author{
Matthew Berman ${ }^{1} \cdot$ Juan Baztan ${ }^{2} \cdot$ Gary Kofinas $^{3} \cdot$ Jean-Paul Vanderlinden $^{2}$. \\ Omer Chouinard ${ }^{4}$ • Jean-Michel Huctin ${ }^{2}$. Alioune Kane ${ }^{5} \cdot$ Camille Mazé $^{6}$. \\ Inga Nikulina ${ }^{7} \cdot$ Kaleekal Thomson $^{8}$
}

Received: 30 August 2018 / Accepted: 26 September 2019

(C) Springer Nature B.V. 2019

\begin{abstract}
Climate change is causing wide-ranging effects on ecosystem services critical to coastal communities and livelihoods, creating an urgent need to adapt. Most studies of climate change adaptation consist of narrative descriptions of individual cases or global synthesis, making it difficult to formulate and test locally rooted but generalizable hypotheses about adaptation processes. In contrast, researchers in this study analyzed key points in climate change adaptation derived from coordinated fieldwork in seven coastal communities around the world, including Arctic, temperate, and tropical areas on four continents. Study communities faced multiple challenges from sea level rise and warmer ocean temperatures, including coastal erosion, increasing salinity, and ecological changes. We analyzed how the communities adapted to climate effects and other co-occurring forces for change, focusing on most important changes to local livelihoods and societies, and barriers to and enablers of adaptation. Although many factors contributed to adaptation, communities with strong self-organized local institutions appeared better able to adapt without substantial loss of well-being than communities where these institutions were weak or absent. Key features of these institutions included setting and enforcing rules locally and communication across scales. Self-governing local institutions have been associated with sustainable management of natural resources. In our study communities, analogous institutions played a similar role to moderate adverse effects from climate-driven environmental change. The findings suggest that policies to strengthen, recognize, and accommodate local institutions could improve adaptation outcomes.
\end{abstract}

Keywords Coastal communities $\cdot$ Climate change $\cdot$ Local institutions $\cdot$ Coastal livelihoods · Common-pool resources

Electronic supplementary material The online version of this article (https://doi.org/10.1007/s10584-01902571-x) contains supplementary material, which is available to authorized users.

Matthew Berman

matthew.berman@uaa.alaska.edu

Extended author information available on the last page of the article 


\section{Introduction}

Climate change is causing wide-ranging effects on ecosystem services critical to coastal livelihoods and living conditions (Wong et al. 2014; McGranahan et al. 2007; Harley et al. 2006; Agardy et al. 2005; Smit et al. 2001). Some communities struggle to adapt to changing environmental conditions along with changes in other forces such as resource development and globalization (Means and Norton 2010; Young 2010). Other communities thrive as they confront equally daunting challenges. The rapid pace and complexity of change creates an urgent need to understand what factors enable some communities to maintain or improve wellbeing while adapting. Identifying the building blocks of community adaptive capacity that promotes these positive adaptation outcomes (Pelling 2011; Smit and Wandel 2006) could inform adaptation policy.

Empirical investigations of climate change adaptation typically consist of stand-alone individual case studies or broad synthesis of global trends, impeding tests of generalizable hypotheses (Berman et al. 2017; Watson 2016; Metcalf et al. 2014; Janssen and Ostom 2006). We report on research that followed a different approach, consistent with Agrawal (2001) that undertook a coordinated set of field studies of climate change adaptation in seven coastal sites including Arctic, temperate, and tropical areas on four continents. Study communities faced multiple environmental challenges including coastal erosion, freshwater salinization, and ecological changes caused by sea level rise, warmer ocean temperatures, and sea ice retreat. We analyzed how communities adapted to the combined effects of climate change and other forces such as government policies, global markets, and new technologies. The analysis examined most important changes to local livelihoods and societies, the degree that climate change was perceived locally, and barriers and enablers to adaptation. Similar methods applied across diverse sites provided opportunities to uncover patterns associated with relatively successful or unsuccessful adaptation.

We found that different factors were relevant in different places. However, communities with strong self-organized local institutions appeared to be adapting without substantial loss of well-being or population, in contrast to communities where these institutions were weak or absent. Key features of these informal as well as formal institutions included setting and enforcing rules locally, and communication across scales. Institutions with these features have long been associated with sustainable management of local natural resources (Dietz et al. 2003; Ostrom 1990, 2005; Ostrom et al. 1999). Similar institutions providing local public services or governance as well as regulating natural resources may play a similar role in helping people adapt to climate effects on ecosystem services.

\section{Methods}

Studies of adaptation to climate change might consider both processes and outcomes (BerrangFord et al. 2011; Adger et al. 2005; McCarthy et al. 2001). The process of adaptation includes drivers of change, how people make sense of the changes occurring around them, the decisions people make to alter livelihood activities, and how institutions mediate the effects (Nelson et al. 2007). Adaptation outcomes reflect the economic and social conditions that result from the adaptation process. Evaluating adaptation outcomes might include appraising the extent that people are able to adjust livelihoods to maintain well-being and assessing feelings of optimism or pessimism about the future. We associate positive adaptation with outcomes indicating that people are thriving in the face of change (Burton 2005). 
An interdisciplinary team of social and natural scientists with research experience in seven diverse coastal regions came together to study climate change and local adaptation. Regions included Arctic, temperate, and tropical areas in countries with differing income levels and governance structures, enabling the study to capture adaptation to a variety of climate-linked environmental changes in different economic, social, and cultural contexts. Arctic regions were somewhat overrepresented to reflect the faster pace of climate change in polar regions (Anisimov et al. 2007). Study sites within each region were selected to take advantage of previous baseline research and established research relationships. Sites included Uummannaq (Greenland), Tiksi (Sakha (Yakutia) Republic, Russian Federation), Wainwright (Alaska, USA), Cocagne-Grande-Digue (New Brunswick, Canada), Bay of Brest (Brittany, France), Mbour (Senegal), and Vypin Island-Chellanam Peninsula (Kerala state, India) (Fig. 1).

Physical and human geography, primary livelihoods, and non-climate drivers of change show great diversity across sites, as summarized in Box 1. The Arctic communities are also all relatively small, situated in sparsely populated regions remote from large population centers, with an indigenous population continuing to practice traditional hunting, fishing, and herding livelihoods to a varying extent. However, governance structures and policy, the nature of potential disruptive industrial development, and the degree that local harvesting is included in the cash economy differ among Arctic sites. All the non-Arctic sites also include residents who practice traditional rural livelihoods, but their proximity to urbanized areas enables new livelihoods to develop such as tourism, intensifies competition for space, and facilitates population mobility.

Wainwright, Alaska, USA: Wainwright is a small predominantly Inupiat community, population 556 (2010 census) located on the Chukchi Sea coast of Alaska. Most households continue to rely on local harvests for food. Climate change has caused a dramatic reduction in sea ice in summer and fall, which affects activities of the community. The community also faces uncertainty regarding offshore oil and gas development in the Chukchi Sea and increased shipping and cruise ship tourism enabled by the loss of sea ice.

Uummannaq, Greenland: Located on a small $\left(12 \mathrm{~km}^{2}\right)$ island in a fjord along the middle of the west coast of Greenland, Uummannaq's predominantly Inuit population of 1282 (2013

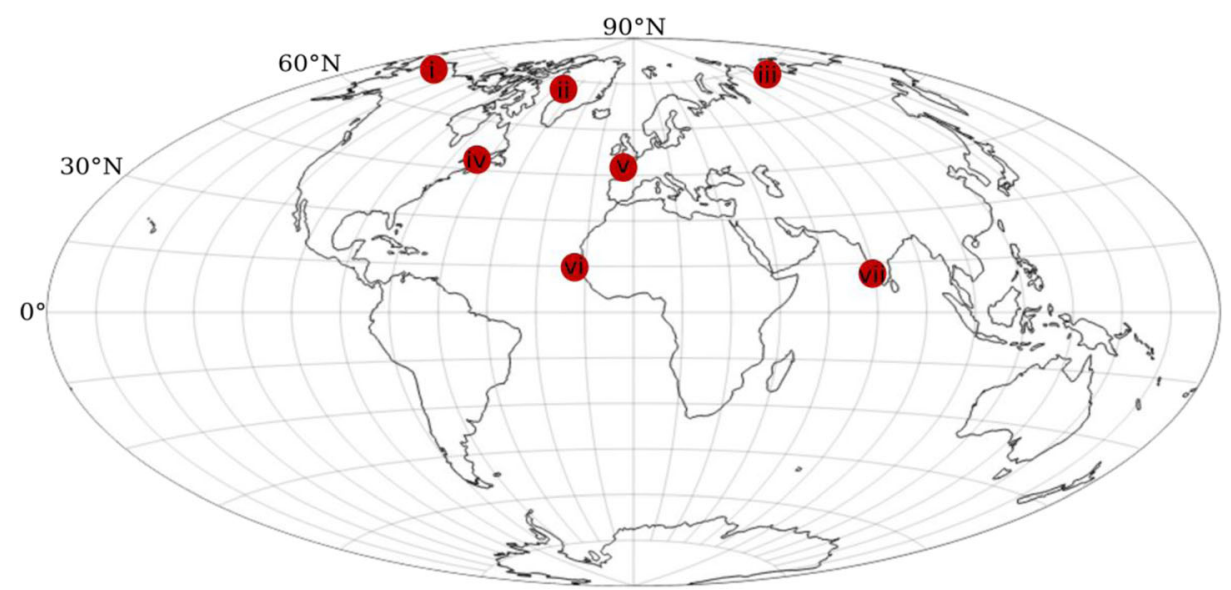

Fig. 1 Location of the study sites: (i) Wainwright (Alaska, USA), (ii) Uummannaq (Greenland), (iii) Tiksi (Sakha (Yakutia) Republic, Russian Federation), (iv) Cocagne-Grande-Digue (New Brunswick, Canada), (v) Bay of Brest (Brittany, France), (vi) Mbour (Senegal), (vii) Vypin Island-Chellanam Peninsula (Kerala state, India) 


\section{Physical geography, climate change effects, and other drivers of change for seven study sites.}

Wainwright, Alaska, USA. Wainwright is a small predominantly Inupiat community, population 556 (2010 census) located on the Chukchi Sea coast of Alaska. Most households continue to rely on local harvests for food. Climate change has caused a dramatic reduction in sea ice in summer and fall, which affects activities of the community. The community also faces uncertainty regarding offshore oil and gas development in the Chukchi Sea and increased shipping and cruise-ship tourism enabled by the loss of sea ice.

Uummannaq, Greenland. Located on a small $\left(12 \mathrm{~km}^{2}\right)$ island in a fjord along the middle of the west coast of Greenland, Uummannaq's predominantly Inuit population of 1,282 (2013 census) has been adapting to a series of changes starting with Danish colonization. Reduction in sea ice cover due to climate change has affected access to the community and local resource harvesting activities. Recent policies that rationalize service delivery and governance and promote demographic urban concentration to reduce administrative costs and support Greenland's longterm aspirations for independence are creating economic and political challenges for the community.

Tiksi, Sakha, Russia. This port town, population 5,063 (2010 census), on the Laptev Sea near the Lena River delta, faces major transformations associated with climate change ranging from the thawing permafrost to increased shipping due to reduction of sea ice in the North-East Passage. During the 1990s, Tiksi experienced a dramatic reduction of economic activity and population following closure of its military installation and changes in national policies toward northern development.

Cocagne-Grande-Digue, New Brunswick, Canada. In the last decade, storms attributed locally to climate change have affected the Cocagne-Grande-Digue coastal area in southeast New Brunswick. Residents of the mostly French-speaking Acadian communities Cocagne, population 2,649, and Grande Digue, 2,261 (2016 census) have been adapting to a variety of externallydriven changes, including shifting from a natural resources-based to a more service-based economy, out-migration, and urbanization from nearby Moncton (population 72,000).

Bay of Brest and Iroise Sea coast, France. The Zone Atelier Brest Iroise (ZABrI) encompasses the Bay of Brest and adjacent coastal areas of the Iroise Sea located along the western part of the Breton peninsula in northwestern France. The Southern part of the Bay is mostly agricultural, while the northern part hosts the city of Brest, metropolitan area population 350,000 (OECD, 2019), a large naval base, and ship yard. Rising sea level is intensifying erosion affecting residents of small communities with population of 1-2,000 along the Iroise Sea coast, exposed to Atlantic winter storms. Climate change is also enhancing eutrophication from agricultural fertilizer runoff and spread of invasive species and toxic algae, affecting coastal fishing livelihoods (Ragueneau et al, 2018).

Vypin Island and Chellanam Peninsula, Kerala, India. The study site in the Cochin estuary, population 198,400 (2011 census, Vypin block) groups tropical coastal Arabian Sea villages surrounding the growing port city of Kochi (population 677,000), in a region that is densely populated even relative to the average for India. The region has a historical legacy of community-based adaptation to environmental change such as to monsoon regime shifts, and has weathered dramatic political and economic changes. Salinization from sea level rise has adversely affected agriculture and drinking water supplies for coastal residents.

Mbour District, Senegal. Located along Senegal's Petite Côte, rapidly growing cities of Mbour $(233,000)$ and Joal-Fadiouth $(46,000)(2013$ census) and their surrounding rural communities rely heavily on fisheries and tourism livelihoods. Artisanal fisheries face increasing competition from export-based industrial fisheries as well as shifts in resource availability that may be influenced by climate change. Beach erosion from rising seas affect tourist operators, and farmers face increased uncertainty regarding rainfall regimes.

Box 1 Physical geography, climate change effects, and other drivers of change for seven study sites 
census) has been adapting to a series of changes starting with Danish colonization. Reduction in sea ice cover due to climate change has affected access to the community and local resource harvesting activities. Recent policies that rationalize service delivery and governance, and promote demographic urban concentration to reduce administrative costs and support Greenland's long-term aspirations for independence are creating economic and political challenges for the community.

Tiksi, Sakha (Yakutia), Russia: This port town, population 5063 (2010 census), on the Laptev Sea near the Lena River delta, faces major transformations associated with climate change ranging from the thawing permafrost to increase shipping due to reduction of sea ice in the North-East Passage. During the 1990s, Tiksi experienced a dramatic reduction of economic activity and population following closure of its military installation and changes in national policies toward northern development.

Cocagne-Grande-Digue, New Brunswick, Canada: In the last decade, storms attributed locally to climate change have affected the Cocagne-Grande-Digue coastal area in southeast New Brunswick. Residents of the mostly French-speaking Acadian communities Cocagne, population 2649, and Grande Digue, 2261 (2016 census), have been adapting to a variety of externally driven changes, including shifting from a natural resources based on a more servicebased economy, out-migration, and urbanization from nearby Moncton (population 72,000).

Bay of Brest and Iroise Sea coast, France: The Zone Atelier Brest Iroise (ZABrI) encompasses the Bay of Brest and adjacent coastal areas of the Iroise Sea located along the western part of the Breton peninsula in northwestern France. The southern part of the bay is mostly agricultural, while the northern part hosts the city of Brest, metropolitan area population 350,000 (OECD 2019), a large naval base, and shipyard. Rising sea level is intensifying erosion affecting residents of small communities with population of 1000-2000 along the Iroise Sea coast, exposed to Atlantic winter storms. Climate change is also enhancing eutrophication from agricultural fertilizer runoff and spread of invasive species and toxic algae, affecting coastal fishing livelihoods (Ragueneau et al. 2018).

Vypin Island and Chellanam Peninsula, Kerala, India: The study site in the Cochin Estuary, population 198,400 (2011 census, Vypin block) groups tropical coastal Arabian Sea villages surrounding the growing port city of Kochi (population 677,000), in a region that is densely populated even relative to the average for India. The region has a historical legacy of community-based adaptation to environmental change such as to monsoon regime shifts and has weathered dramatic political and economic changes. Salinization from sea level rise has adversely affected agriculture and drinking water supplies for coastal residents.

Mbour District, Senegal: Located along Senegal's Petite Côte, rapidly growing cities of Mbour $(233,000)$ and Joal-Fadiouth $(46,000)$ (2013 census) and their surrounding rural communities rely heavily on fisheries and tourism livelihoods. Artisanal fisheries face increasing competition from export-based industrial fisheries as well as shifts in resource availability that may be influenced by climate change. Beach erosion from rising seas affects tourist operators, and farmers face increased uncertainty regarding rainfall regimes.

Assessing positive or successful (Moser and Boykoff 2013) adaptation would ideally involve measuring changes in indicators of well-being such as employment, income, and health status. A rich analysis would also address the distribution of outcomes among households and genders. Systematic data on local outcomes are available for only a few of the study sites, however, making quantitative comparisons infeasible. Our information about outcomes is therefore largely qualitative, drawn from participatory research and interviews. 
The team developed a common general methodological approach based on modified grounded theory (Strauss and Corbin 1997; McCreaddie and Payne 2010; Charmaz 2006) to collect and analyze data from semi-structured interviews and focus group discussions with key informant households and stakeholder representatives. Previous research by study team members helped identify key informants able to provide representative information about conditions in each site. In some cases, on-site participant observations supplemented interviews. Fieldwork aimed to identify current perceptions of environmental and other changes, attribution of environmental change to climate drivers, and adaptation practices and their relationship to institutions and institutional change in each site. Details for how best to implement the general approach locally were left to the individual researchers, permitting analysis of additional issues of particular local interest. Table 1 summarizes the site-specific methodology. An Appendix provided as supplementary material contains additional information and references to previous studies providing baseline data and relevant reports on individual sites incorporated into the analysis.

Coordination among study teams was implemented at four 4-day retreats organized within or near study sites, where researchers exchanged information about their methods and observations, held group discussions, and conducted field visits. The first two retreats addressed methods and planning for field data collection. At the third retreat, researchers discussed how to organize reporting of findings to facilitate analysis of similarities and differences among sites, and agreed to provide information for a common template. The template requested information on the following items: (1) primary livelihoods, (2) main environmental changes observed and whether attributed locally to climate change, (3) non-climate drivers of change; (4) greatest impacts on livelihoods and social/cultural conditions; (5) important institutions and the role they play; (6) most important challenges and assets for adaptation; and (7) other important observations regarding adaptation. Information from the template for each site was reviewed and discussed by the team at the fourth retreat.

The fieldwork was designed to understand adaptation processes: to record environmental changes locals identified and how they were adapting. However, in compiling and analyzing results in the template, patterns emerged in the discussion at the fourth retreat for several key attributes associated with positive adaptation outcomes, such as a relatively stable population, minimal social disruption, impoverishment, and other adverse well-being outcomes, and prevailing attitudes of confidence in the future.

\section{Results from the study sites}

Table 2 summarizes findings from fieldwork for the effects of the climate and non-climate drivers of change on coastal livelihoods, adaptations, and living conditions, along with the most important challenges and assets for adaptation in each site. The supplementary Appendix contains a synopsis of findings at each study site regarding effects of climate and other drivers on communities. Residents of all three Arctic sites noted rapidly diminishing sea ice. Sea level rise is damaging freshwater supplies in Vypin Island-Chellanam Peninsula and, combined with increased storm severity, is eroding and flooding coastlines in many sites. Interview respondents in all study sites reported changes in distribution and abundance of harvested species and other consequences of marine ecological change. However, attribution of these and other effects to climate change varied, with residents of Arctic sites most likely and residents of tropical sites least likely to associate observed environmental changes with a climate driver. 


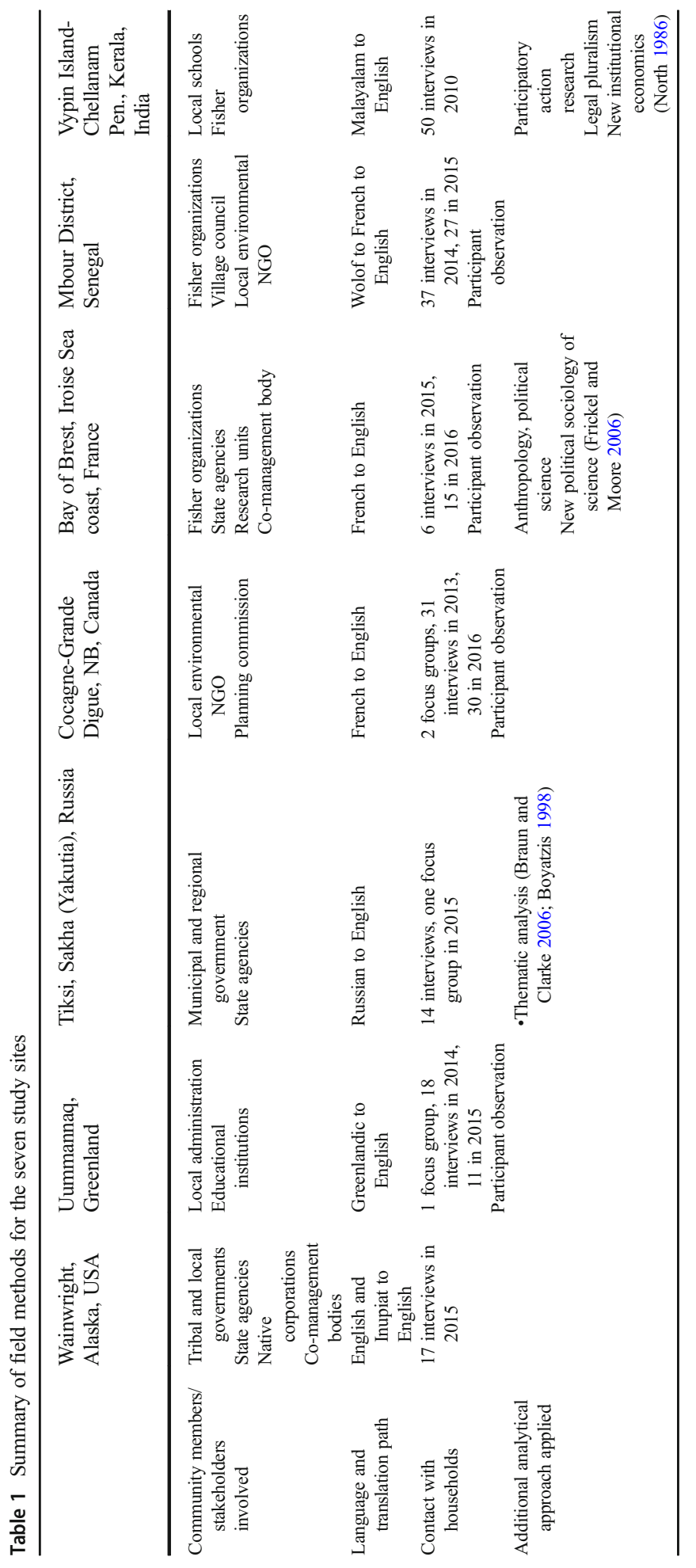




\subsection{Effects on livelihoods and living conditions}

All seven study sites revealed significant effects to livelihoods and living conditions due to climate change. Effects of other external drivers such as technology change, urbanization, resource development, and state policy changes were also important everywhere, and in many cases dominated effects of climate change. In effect, residents of all coastal communities were challenged with adapting to climate change as a cumulative effect, along with other contemporaneous forces of change.

The diverse geographies and variety of changes to coastal environments led to differing effects at each site (Table 2, column 3). Shared climate-related impacts to livelihoods included reduced productivity (Mbour, Tiksi, Bay of Brest, Vypin-Chellanam) and impeded access to coastal resources (Wainwright, Cocagne-Grande Digue, Vypin-Chellanam), although from heterogeneous proximate mechanisms. Main non-climate livelihood effects included competition for land and resources from urbanization and industrial fishing at all non-Arctic sites, and loss of public service jobs at Uummannaq and Tiksi. Despite different effects, strategies residents used to adapt to these changes followed broad patterns that people in all environments use to adapt to environmental uncertainty. These strategies include mobility (spreading risk across space), storage (spreading risk over time), communal pooling (spreading risk among households through sharing or through insurance contracts if available), and efforts to reduce uncertainty through building protective infrastructure as well as through livelihood diversification (Huntington et al. 2017; Berman 2013; Agrawal 2010). Study site residents responded to the new risks created by environmental change and other drivers by intensifying such activities (Table 2, column 4). Mobility increased in all sites except Wainwright and Bay of Brest. Residents in five sites - Wainwright, Uummannaq, Bay of Brest, Mbour, and Vypin/ Chellanam-diversified livelihood activities.

Shared adaptation strategies among sites, combined with similarities in non-climate drivers, led to a number of common effects on living conditions (Table 2, column 5). Wainwright, Cocagne-Grande Digue, Bay of Brest, and Mbour experienced increased uncertainty. Fewer remaining young adults in sites with out-migration-Uummannaq, Cocagne-Grande Digue, and Tiksi-led to population aging, while social stratification increased in the two tropical sites.

\subsection{Assets and impediments to adaptation}

Table 3 summarizes biggest challenges and assets for adaptation, along with notes from fieldwork providing important relevant context for interpreting the results. Limited local political autonomy arose as a big challenge for adaptation in virtually all sites, although the way that national authorities accommodated local institutions and the responses from residents differed widely. Wainwright, Cocagne-Grande Digue, and Vypin/Chellanam are embedded in federal political systems with a history of shared multi-scale governance and strong informal institutions. Tiksi and Uummannaq are also embedded in nominally federal systems, but with limited local autonomy. Top-down governance and lack of coordination across governance scales, and the associated effects on local collective action to fix problems, created challenges for all sites except Wainwright and Vypin/Chellanam, where local institutions were strongest.

Assets for adaptation represent key components of adaptive capacity (Turner II et al. 2003; Adger 2006; Gallopin 2006; Smit and Wandel 2006) for coping with the effects of climate and other changes. In addition to local institutions noted for all sites except Mbour and Tiksi, 


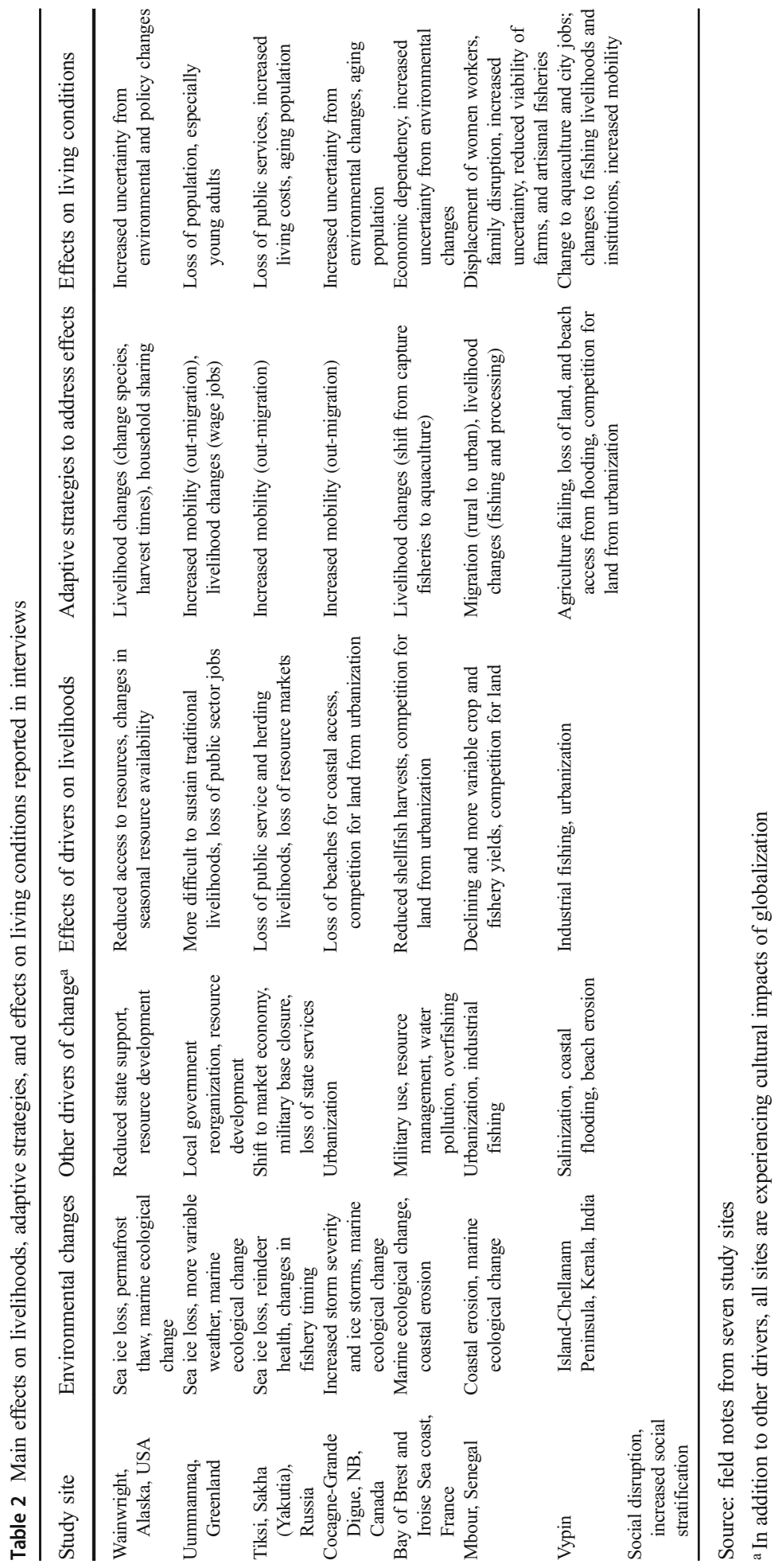




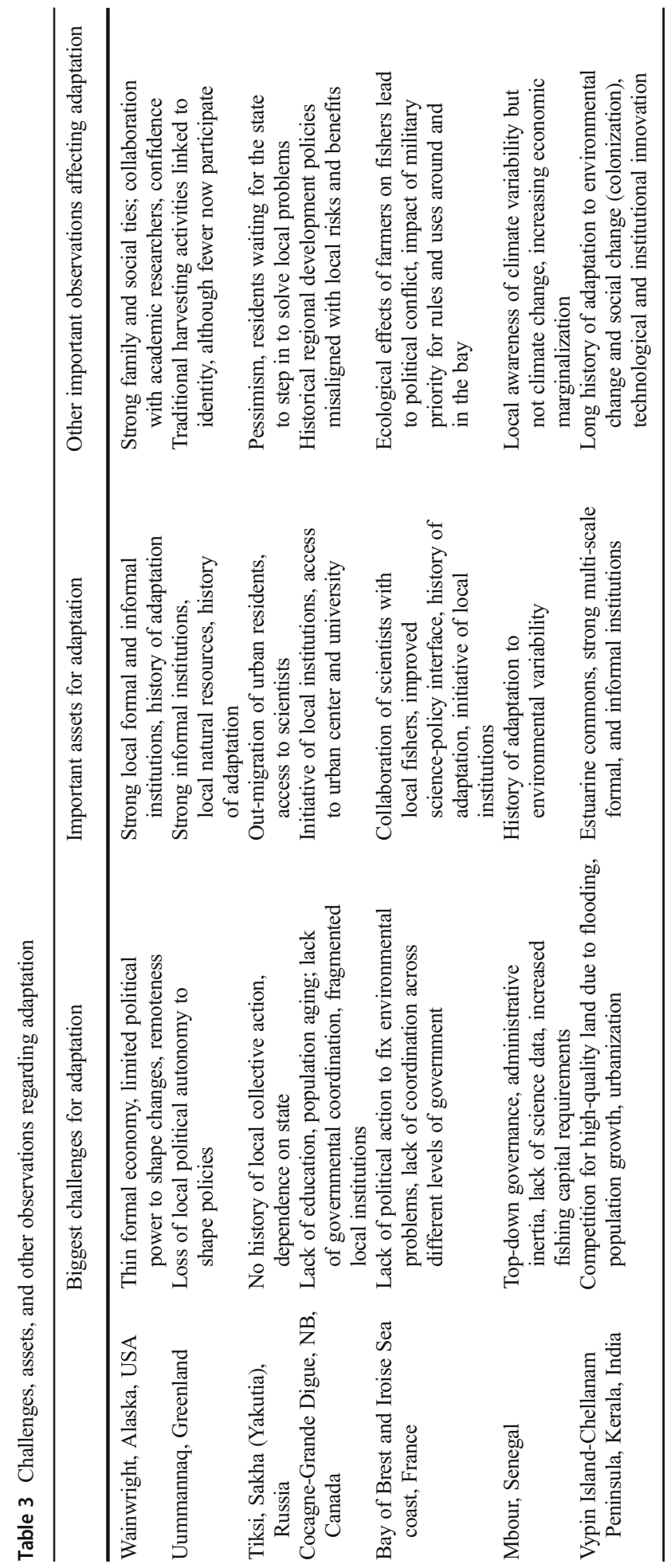


residents of many sites benefited from collective memories of adaptation to changes in the past. Although the contemporary challenges of climate change and co-occurring drivers are unique, study communities have been adapting to environmental, economic, and political change for many generations (Kennedy et al. 2018). Past experiences with adaptation may reduce anxiety over the challenges of adapting to increased uncertainty. In Uummannaq, for example, memory of successful past adaptation played a large role in residents' optimism regarding future adaptation (Baztan et al. 2017).

\subsection{Positive adaptation outcomes}

Although our field research was designed to understand adaptation processes rather than assess outcomes, it did provide a rich portfolio of qualitative information that allowed us to identify how well communities in each study site were managing change. We observed some communities apparently thriving despite potentially disruptive change, while others were clearly struggling. Among Arctic sites, Wainwright residents appeared confident and thriving relative to those of Uummannaq; however, both were faring better than Tiksi residents, who were pessimistic that anything other than direct state intervention could improve their deteriorating living conditions. Cocagne-Grand Digue and Bay of Brest presented a mixed picture, with communities achieving limited success in solving problems locally. In the more impoverished tropical sites, residents of the Cochin Estuary were working through problems as they arose to sustain coastal livelihoods, continually developing local solutions to manage change despite formidable social and economic challenges. Mbour residents, facing similar challenges, reported increasing insecurity and vulnerability.

\section{Discussion}

Despite enormous geographic diversity, the coastal sites share many similarities regarding climate-driven environmental change, including marine ecological change, accelerated coastal erosion at all five wave-affected sites, and sea ice loss in the three Arctic sites. All sites are also experiencing effects from powerful external non-climate drivers such as globalization, resource development, urbanization, and national political change. We observed residents in all study communities making adjustments to livelihoods to accommodate the new physical, ecological, and economic changes these drivers are causing. Nevertheless, adaptation outcomes varied widely among sites. The differences in outcomes that we observed do not appear to be related to relative wealth, geography, or the pace or type of environmental change. Of the two sites that appear most resilient, Wainwright is relatively affluent, while Vypin Island-Chellanam Peninsula is poor, though rapid climate-related environmental change is disrupting livelihoods in both places. The contrast among the three Arctic sites, and between the two tropical sites, is as great as across all sites in our study.

A close examination of the adaptation process in the different communities found in our field research (see supplementary Appendix) revealed that the structure and performance of local institutions distinguished the relatively high-functioning sites from those experiencing more difficulty. Among the seven coastal sites, Wainwright 
and Vypin Island-Chellanam Peninsula had the richest portfolio of active local institutions, both formal and informal. Such institutions were weakest in Mbour and Tiksi.

Agrawal (2010), analyzing 118 cases of community adaptation in the United Nations Framework Convention on Climate Change (UNFCC) database, found that local institutions played a central role in nearly all cases. Local formal and informal institutions structured household risk-mitigation activities either directly or indirectly, by filtering external interventions. The experience in our study sites goes beyond this finding, consistent with Alam et al. (2013), to suggest that strong local formal and informal institutions enable communities to attain better adaptation outcomes. Communities in developing regions dominate the cases in the UNFCC database analyzed by Agrawal (2010); our research found a similar role for local institutions in higher income sites, too.

Since ecosystem services important to coastal livelihoods are locally heterogeneous, local institutions may have an advantage over centrally driven solutions to problems that develop from effects of climate change. Rural coastal livelihoods often involve exploitation of common-property resources (Curran and Agardy 2002), and this generalization applies to our study communities. Local self-managing institutions represent a way to manage common-pool resources sustainably (Ostrom et al. 1999) that have been shown to dampen negative effects of socioeconomic inequality (Andersson and Agrawal 2011). Local institutions might therefore be more likely than state resource management to generate positive adaptation outcomes when drivers of change exacerbate economic or political inequality. Some of the most important local institutions in our study communities, both formal and informal, are involved in managing common-pool resources. Colonization and modernization have strained these institutions throughout the Arctic, and urbanization has disrupted local commons management in the other sites. However, these disruptive forces do not seem to have had the same damaging effect Wainwright and Vypin-Chellanam as in the other sites: local institutions there have endured and evolved, their role and authority has not diminished, and new institutions have even appeared.

Pretty and Ward (2001) argued that local institutions managing common-property resources nurture the four building blocks of social capital - trust, reciprocity, norms, and connectedness (including across scales) - that help communities to develop other local institutions addressing adaptation challenges. Recognizing authority of local institutions and accommodating local rules are two features Ostrom (1990) associated with sustainable local commons management, and insufficient engagement and accommodation of organized local interests can create a barrier to adaptation (Shinn 2016; Raymond and Robinson 2013). Higher authorities in Wainwright and Vypin-Chellanam appear to have been willing to recognize and accommodate local institutions, including those providing or regulating a wide variety of local public services as well as natural resources. Examples of such accommodation include authorization of a new fall whale hunt in Wainwright, provision of fresh drinking water on Vypin Island, and breaks in the sea wall on Chellanam Peninsula. Understanding complex cross-scale interactions helps identify why the local institutions succeeded in some sites but not in others (Young 2011; Ostrom 2007). Canada's strongly federal system delegates substantial powers to provincial governments. Cocagne-Grande Digue residents struggled to gain support from provincial agencies when local needs were not aligned with provincial resource development goals (Ommer and the Coasts Under Stress Research Project Team 2007; Ommer 2006). In France's Bay of Brest region, powerful national 
agricultural interests stymied local attempts to control fertilizer use to protect coastal livelihoods from eutrophication, despite the new governance structures created over the past decade to promote sustainable resource management.

The three Arctic sites illustrate how closely self-governing institutions for managing common-pool resources align with other local institutions in the same place. Marine mammal harvest critical to Wainwright coastal subsistence livelihoods is governed by national legislation recognizing traditional harvesting rights, implemented through co-management organizations that give broad deference to informal local institutions. Formal institutions govern land use decisions important to coastal livelihoods, but when conflicts arise, Wainwright can rely on the North Slope Borough regional government, which is generally responsive to community needs and a defender of community values. In contrast, renewable resources in Uummannaq and Tiksi are managed centrally. Local government has limited autonomy and budget in Tiksi and has been displaced from Uummannaq to the distant Ilulissat. Systems managing the commons centrally may be slow to respond as local conditions change, and therefore less flexible for adapting to rapid change. Ineffectiveness of national government institutions to manage competition for resources in Mbour illustrates this point.

\section{Conclusion}

Coastal communities stand at the front lines of climate change, confronting impacts from changes to both marine and terrestrial systems. We studied adaptation processes in seven coastal sites around the world as their communities addressed climate-driven environmental change and other impacts. Our research differed from other studies by fielding a set of parallel case studies simultaneously in multiple sites with different ecosystems, political systems, and levels of development. While many similarities appeared across sites in the immediate physical effects of climate change, the way that these changes affected communities was locally specific.

In reviewing the adaptation processes underway in each site, we found that local institutions, informal, and formal played a prominent role in achieving positive adaptation outcomes. Strong local institutions appeared to be a necessary, but not sufficient condition for successful coastal adaptation. The most favorable outcomes appeared in communities where strong local informal and formal institutions obtained cross-scale accommodation and support from higher levels of government to solve local problems. Local self-governing institutions have long been associated with sustainable local management of natural resources (Dietz et al. 2003; Ostrom et al. 1999; Ostrom 1990). The findings suggest that similar institutions, including those providing or regulating a wide variety of local public services as well as natural resources, may play a similar role in helping people adapt to effects of climate change.

Although the study communities with strong institutions were able to adjust to current climate impacts, future combined effects of climate and other forces could eventually overwhelm their adaptive capacity. This study adds to the growing body of literature that documents the importance of strong local institutions in managing adaptation challenges. If the results hold, they add to the growing evidence suggesting that designing and implementing policies to strengthen local self-governance increase community resilience in climate adaptation. 
The study was designed to analyze processes of adaptation rather than evaluate factors relating to differential outcomes. However, efforts during project team retreats to coordinate reporting and analysis of results related to adaptation processes using a common template enabled some common patterns of association of processes with outcomes to be seen that might have otherwise been missed. The experience with this study suggests that a similar process to develop a common framework for reporting qualitative results might be productive for generalizing findings across sites, such as, for example, in a meta-analysis of case studies of vulnerability and adaptive capacity.

Funding information This research received financial support from the Belmont Forum International Opportunities Fund, with contributions from Agence Nationale de la Recherche, France; National Science Foundation, USA; Ministry of Earth Science, India; Russian Foundation for Basic Research, Russia; and Social Science and Humanities Research Council of Canada, Canada.

\section{References}

Adger N (2006) Vulnerability. Global Environmental Change 16:268-281

Adger WN, Arnell N, Tompkins E (2005) Successful adaptation to climate change across scales. Global Environmental Change 15:77-86

Agardy T, Alder J, Dayton P, Curran S, Kitchingman A, Wilson M, Catenazzi A, Restrepo J, Birkeland C, Blaber S, Saifullah S, Branch G, Boersma D, Nixon S, Dugan P, Davidson N, Vorosmarty C (2005) Chapter 19: Coastal systems. In: Hassan R, Scholes R, Ash N (eds) Ecosystems and Human Well-being: Current State and Trends. Island Press, Washington, DC http://www.millenniumassessmentorg/documents/document288 aspx.pdf

Agrawal A (2001) Common property institutions and sustainable governance of resources. World Development 29(10):1649-1672. https://doi.org/10.1016/S0305-750X(01)00063-8

Agrawal A (2010) Local institutions and adaptation to climate change. In: Means R, Norton A (eds) Social dimensions of climate change equity and vulnerability in a warming world. The World Bank, Washington, DC, pp 173-197

Alam M, Ahammad R, Nandy P, Rahman S (2013) Coastal livelihood adaptation in changing climate: Bangladesh experience of NAPA priority project implementation. In: Shaw R, Mallick F, Islam (eds) Climate change adaptation actions in Bangladesh. Springer, Dordrecht, pp 253-276

Andersson K, Agrawal A (2011) Inequalities, institutions, and forest commons. Global Environmental Change 21(3):866-875

Anisimov O, Vaughan D, Callaghan T, Furgal C, Marchant H, Prowse T, Vilhjálmsson J, Walsh J (2007) Polar regions (Arctic and Antarctic). In: Parry M, Canziani O, Palutikof J, van der Linden P, Hanson C (eds) Climate Change 2007: Impacts, Adaptation and Vulnerability. Contribution of Working Group II to the Fourth Assessment Report of the Intergovernmental Panel on Climate Change. Cambridge University Press, Cambridge, pp 653-685

Baztan J, Cordier M, Huctin J-M, Zhu Z, Vanderlinden J-P (2017) Life on thin ice: insights from Uummannaq, Greenland for connecting climate science with Arctic communities. Polar Science 13:100-108. https://oi. org/10.1016/jpolar201705002

Berman M (2013) Modeling regional dynamics of human-Rangifer systems: a framework for comparative analysis. Ecology and Society 18(4):43. https://doi.org/10.5751/ES-05535-180443

Berman M, Kofinas G, BurnSilver S (2017) Measuring Community Adaptive and Transformative Capacity in the Arctic Context. In: Fondahl G, Wilson G (eds) Northern sustainabilities: understanding and addressing change in the Circumpolar World. Springer, Dordrecht, pp 59-76

Berrang-Ford L, Ford JD, Paterson J (2011) Are we adapting to climate change? Global Environmental Change 21(1):25-33

Boyatzis R (1998) Transforming qualitative information: thematic analysis and code development. Sage, Thousand Oaks

Braun V, Clarke V (2006) Using thematic analysis in psychology. Qualitative Research in Psychology 3:77-101. https://doi.org/10.1191/1478088706qp063oa

Burton I (2005) Adapt and thrive: options for reducing the climate change adaptation deficit. Policy Options 27 
Charmaz K (2006) Constructing grounded theory: a practical guide through qualitative analysis. Sage Publications, Thousand Oaks

Curran SR, Agardy T (2002) Common property systems, migration, and coastal ecosystems. Ambio 31(4):303305

Dietz T, Ostrom E, Stern PC (2003) The struggle to govern the commons. Science 302(5652):1907-1912. https://doi.org/10.11126/science1091015

Frickel S, Moore K (2006) The new political sociology of science: institutions, networks, and power. University of Wisconsin Press, Madison

Gallopin GC (2006) Linkages between vulnerability, resilience, and adaptive capacity. Global Environmental Change 16:293-303

Harley C, Hughes AR, Hultgren K, Miner B, Sorte C, Thornber C, Rodriguez L, Tomanek L, Williams S (2006) The impacts of climate change in coastal marine systems. Ecology Letters 9:228-241. https://oi. org/10.1111/j1461-0248200500871x

Huntington H, Begossi A, Fox Gearheard S, Kersey B, Loring P, Mustonen T, Paudel P, Silvano R, Vave R (2017) How small communities respond to environmental change: patterns from tropical to polar ecosystems. Ecology and Society 22(3):9

Janssen M, Ostom E (2006) Resilience, vulnerability, and adaptation: a cross-cutting theme of the International Human Dimensions Programme on Global Environmental Change. Global Environmental Change 16:237239

Kennedy G, Raimonet M, Berman M, Gaye N, Huctin J-M, Thomson K, Vanderlinden J-P (2018) Environmental history and the concept of agency: improving understanding of local conditions and adaptations to climate change in seven coastal communities. Global Environment 11(2):405-433. https://doi.org/10.3197 /ge.2018.110209

McCarthy J, Canziani O, Leary N, Dokken D, White K (eds) (2001) Climate Change 2001: impacts, adaptation, vulnerability. Cambridge University Press, Cambridge

McCreaddie M, Payne S (2010) Evolving grounded theory methodology: towards a discursive approach. International Journal of Nursing Studies 47(6):781-793

McGranahan G, Balk D, Anderson B (2007) The rising tide: assessing the risks of climate change and human settlements in low elevation coastal zones. Environment and Urbanization 19(1):17-37

Means R, Norton A (eds) (2010) Social dimensions of climate change equity and vulnerability in a warming world. The World Bank, Washington, DC

Metcalf S, van Putten E, Frusher S, Tull M, Marshall N (2014) Adaptation options for marine industries and coastal communities using community structure and dynamics. Sustainability Science 9:247-261. https:/doi. org/10.1007/s11625-013-0239-Z

Moser S, Boykoff M (2013) Climate change and adaptation success: the scope of the challenge. In: Moser S, Boykoff M (eds) Successful adaptation to climate change: linking science and policy in a rapidly changing world. Routledge, New York, pp 1-34

Nelson DR, Adger WN, Brown K (2007) Adaptation to environmental change: contributions of a resilience framework. Annual Review of Environment and Resources 32(1):395-419. https://doi.org/10.1146/annurev. energy.32.051807.090348

North D (1986) The new institutional economics. Journal of Institutional and Theoretical Economics 142(1): 230-237

OECD (2019) Functional Urban Areas in OECD Countries: France. http://www.oecd.org/cfe/regionalpolicy/France-bis.pdf (Retrieved March 11, 2019)

Ommer RE (2006) Coasts under stress: policy reflections, booklet for policy-makers. Institute of Social and Economic Research Faculty of Arts Publications, Memorial University of Newfoundland, St. John's

Ommer RE, the Coasts Under Stress Research Project Team (2007) Coast under stress: restructuring and socialecological health. McGill-Queen's University Press, Montreal

Ostrom E (1990) Governing the commons: the evolution of institutions for collective action. Cambridge University Press, Cambridge

Ostrom E (2005) Understanding institutional diversity. Princeton, Princeton University Press

Ostrom E (2007) A diagnostic approach for going beyond panaceas. Proceedings of the National Academy of Sciences 104:15181-15187

Ostrom E, Gardner R, Walker J (1994) Rules, games, and common-pool resources. Univ of Michigan Press, Ann Arbor. https://doi.org/10.3998/mpub9739

Ostrom E, Burger J, Field C, Norgaard R, Policansky D (1999) Revisiting the commons: local lessons, global challenges. Science 284:278-282

Pelling M (2011) Adaptation to climate change: from resilience to transformation. Routledge, Abingdon

Pretty J, Ward H (2001) Social capital and the environment. World Development 29:209-227 
Ragueneau O, Raimonet M, Mazé C, Coston-Guarini J, Chauvaud L, Danto A, Grall J, Jean F, Paulet Y-M, Thouzeau G (2018) The impossible sustainability of the Bay of Brest? Fifty years of ecosystem changes, interdisciplinary knowledge construction and key questions at the science-policy-community interface. Frontiers of Marine Science 5:124. https://doi.org/10.3389/fmars.2018.00124

Raymond C, Robinson G (2013) Factors affecting rural landholders' adaptation to climate change: insights from formal institutions and communities of practice. Global Environmental Change 23(1):103-114

Shinn J (2016) Adaptive environmental governance of changing social-ecological systems: empirical insights from the Okavango Delta, Botswana. Global Environmental Change 40:50-59

Smit B, Wandel J (2006) Adaptation, adaptive capacity and vulnerability. Global Environmental Change 16(3): 282-292

Smit B, Pilifosova O, Burton I, Challenger B, Huq S, Klein RJT, Yohe G, Adger N, Downing T, Harvey E, Kane S, Parry M, Skinner M, Smith J (2001) Adaptation to climate change in the context of sustainable development and equity. In: McCarthy J, Canziani O, Leary N, Dokken D, White K (eds) Climate Change 2001: impacts, adaptation, and vulnerability. Cambridge U. Press, Cambridge, pp 877-912

Strauss A, Corbin J (1997) Grounded theory in practice. Sage Publications, Thousand Oaks

Turner B II, Kasperson R, Matson P, McCarthy J, Corell R, Christensen L, Eckley N, Kasperson J, Luers A, Martello M, Polsky C, Pulsipher A, Schiller A (2003) A framework for vulnerability analysis in sustainability science. Proceedings of the National Academy of Sciences 100:8074-8079

Watson D (2016) Literature review: principles and practices of coastal adaptation in the era of climate change. In: Johnson M, Bayley A (eds) Coastal change, ocean conservation and resilient communities. Springer, Dordrecht, pp 23-40

Wong P, Losada I, Gattuso J-P, Hinkel J, Khattabi A, McInnes K, Saito Y, Sallenger A (2014) Coastal systems and low-lying areas. In: Field C, Barros V, Dokken D, Mach K, Mastrandrea M, Bilir T, Chatterjee M, Ebi K, Estrada Y, Genova R, Girma B, Kissel E, Levy A, MacCracken S, Mastrandrea P, White L (eds) Climate Change 2014: impacts, adaptation, and vulnerability part A: Global and Sectoral Aspects Contribution of Working Group II to the Fifth Assessment Report of the Intergovernmental Panel on Climate Change. Cambridge University Press, Cambridge, pp 361-409

Young O (2009) Institutional dynamics: resilience, vulnerability and adaptation in environmental and resource regimes. Global Environmental Change 20(3):378-385

Young O (2011) Land use, environmental change, and sustainable development: the role of institutional diagnostics. International Journal of the Commons 5(1):66-85. https://doi.org/10.18352/ijc244

Publisher's note Springer Nature remains neutral with regard to jurisdictional claims in published maps and institutional affiliations.

\section{Affiliations}

\section{Matthew Berman ${ }^{1} \cdot$ Juan Baztan ${ }^{2} \cdot$ Gary Kofinas $^{3} \cdot$ Jean-Paul Vanderlinden $^{2} \cdot$ Omer Chouinard $^{4}$ • Jean-Michel Huctin ${ }^{2} \cdot$ Alioune Kane $^{5} \cdot$ Camille Mazé $^{6} \cdot$ Inga Nikulina ${ }^{7}$. Kaleekal Thomson ${ }^{8}$}

1 Institute of Social and Economic Research, University of Alaska Anchorage, 3211 Providence Drive, Anchorage, AK 99508, USA

2 Université de Versailles Saint-Quentin-en-Yvelines, 11 Boulevard d'Alembert, 78280 Guyancourt, France

3 University of Alaska Fairbanks, P.O. Box 757000, Fairbanks, AK 99775, USA

4 Université de Moncton, Pavillon Léopold-Taillon 18, Avenue Antonine-Maillet, Moncton, NB E1A 3E9, Canada

5 Université Cheikh Anta Diop, Boulevard Martin Luther King, BP 5005, Dakar, Senegal

6 Centre National de la Recherche Scientifique (Brest), UMR 6539 Laboratoire des Sciences de l'Environnement Marin IUEM, Technopôle Brest-Iroise, rue Dumont d’Urville, 29280 Plouzané, France

7 North-Eastern Federal University, Yakutsk, Sakha, Russia

8 Cochin University of Science and Technology, Cochin, Kerala 682016, India 